\title{
COVID, Existentialism and Crisis Philosophy
}

\section{Wim Vandekerckhove ${ }^{1}$ iD}

Published online: 2 June 2020

(C) Springer Nature Switzerland AG 2020

\begin{abstract}
This is the editorial for Vol 19 Issue 2 of Philosophy of Management. A reflection is made on COVID-19 measures and a call for papers is made to explore the crisis through philosophical inquiry on 1) disaster management and 2) existentialist views of work. Guidance is given based on papers published previously in the journal, and on Camus' La Peste / The Plague.
\end{abstract}

Keywords Camus $\cdot$ Disaster $\cdot$ Existentialism

How could this editorial not be about the pandemic? It has affected our lives in various ways. It has also affected our scholarly community. We postponed the Philosophy of Management conference to July 2021, thanks to the helpful people at St Anne's College, Oxford University.

I remember participating early April in a (of course) webinar on compliance, in which not a single reference was made to COVID-19 or lockdown measures. Already then, that was a very awkward experience, like being in a time bubble. It had felt unreal and made me realise how the pandemic has irreversibly affected our imagination and thinking. Like many of you, I've been discussing (online) with friends about whether that impact would wane or sustain. Will this change our outlook on life, our priorities in life? Or will we rush back to business-asusual?

I am very much looking forward to see how our Philosophy of Management scholarship will analyse and debate this moment - as episode or as pivot - and I am hereby explicitly welcoming your manuscripts. To give some guidance as to where that scholarly discussion can start from, I browsed previous volumes of our journal. Just within our Philosophy of Management journal, we published more than 100 papers that included some reference to 'crisis'. Most of those make a reference to organizational crises or the global economic crisis of 2007. An exception is Muhr and Lemmergaard (2009) who write about school shootings. That brings us to crises that involve death, i.e. existential crises.

At least two broad routes of inquiry could be taken. One is philosophical inquiry into disaster management. The other is inquiry into work from an existentialist philosophy. With

Wim Vandekerckhove

w.vandekerckhove@greenwich.ac.uk

1 Centre for Research on Employment and Work (CREW), University of Greenwich, London, UK 
regard to the first route, a bunch of papers on disaster management, published in 2009 in this journal, can form a useful scholarly basis to philosophically inquire into COVID-19 management. Tanguay-Renaud (2009) discusses public emergencies and asks what it is about an emergency that justifies 'emergency powers'. Reading that paper again I found it fascinating how, 11 years later, the framework and analysis set out by Tanguay-Renaud (2009) keeps its relevance effortlessly. The author uses Hurricane Katrina - and its wrecking of New Orleans in 2005 - as a concrete example. It would be interesting to reapply that analysis to COVID-19 and the various geopolitical locations where 'emergency powers' were invoked to manage this crisis. Or was it to manage something else? Tanguay-Renaud (2009: 31) defines emergencies as 'situations, often unforeseen, in which there is a risk of significant harm and a need to act urgently if the harm is to be averted or minimised'. We often evoke an emergency to get others to do something, or to accept certain behaviour. A public emergency is where an intervention of the government is required, i.e. an emergency is presented as public (rather than private) to call-in duties a government has to intervene. Scale of the emergency can be a valid reason, although that remains contingent on the government's capacity, argues Tanguay-Renaud (2009). There are also role-inherent duties the government has with regard to emergencies. Roles come with duties, and promises made create responsibilities and roles. Tanguay-Renaud (2009) asks what the government's inherent duty is, beyond a general duty to protect? A duty is stronger if previous actions have caused inadequate infrastructure to prevent harm. For Tanguay-Renaud, the relevance is in decades of underinvestment in New Orleans infrastructure. For us today, we immediately think of health-care policies that have determined resourcefulness (or resourcelessness) of public healthcare infrastructure. In a more generalising sense, we can reconsider lean versus slack management.

But, argues Tanguay-Renaud (2009), morality applies to agents, not roles. The implementation is that agents cannot hide behind a role to duck duties. If a role requires something immoral then agents should refuse to play the role - I'm thinking of the PPE-whistleblowers now and those trying to silence them. If anything, roles add considerations for agents to make, rather than shield agents or simplify moral duties. A crucial consideration for agents in governmental roles is what Bernard Williams (2005) call the first question of politics, namely the 'securing of order, protection, safety, trust, and the conditions of cooperation'. Williams adds that it is the 'first' question because solving it allows to ask the other questions, but it is not a question that can be answered once and for always. Instead, it is a question that needs a solution all the time. Also in emergencies. Tanguay-Renaud (2009) turns to Walzer to explore solutions to that 'first question' in emergency situations. Walzer's notion of supreme emergencies denotes situations where two absolute duties are in conflict. In the case of 'emergency powers', in which parliaments and other accountability mechanisms are cut out of political mechanisms, the conflicting absolutes are 'life of the community' and 'life of the people'. It occurs to me -as I am reading headlines of GDP drops of more than $30 \%$ - we might want to consider economic vitality as another absolute. Of course, Walzer's considerations are made in the context of war. Hence, rephrasing the dilemma so it becomes suitable for managing organizations and workplaces, the question amounts to considering what justifies the sacrificing of X to save or achieve Y. Walzer's answer is that we can indeed make that choice, more precisely in favour of the political community, and thus long-term trumps short-term. Tanguay-Renaud (2009) however, is not that easily convinced. Why, the author asks, does Walzer elevate political community over family, friendship, religious or professional community? Indeed, in our COVID-19 times, what community had the 'elevated' status? Was it family, or did quarantine measures reduce families to housing composition? We hear that 
prevalence of domestic violence peaked during lockdown. At the same time we hear that postlockdown employers might be more enthusiast about telework from home. However, I've never seen domestic violence discussed in scholarship as a risk factor of home work. So, what other blind spots are starting to show now?

John (2009) also tackles Walzer's position on 'supreme emergencies'. The paper takes a closer look at how we are justifying quarantine in the face of an emergency. John (2009) argues that there are two ways in which actions are prohibited during emergencies: by adopting 'threshold deontology' or by rethinking the nature of self-defence. John (2009) shows why neither strategy is fully convincing, and then improves the self-defence justification by developing an 'epistemic' account of the ethics of emergency in both war and public health. Melnick and Bernheim (2009) demonstrate how public health officials can use a code of ethics when making decisions about allocating ventilators during an influenza pandemic. Ventilators have also been a scarce resource during the COVID-19 pandemic and were, at least in the UK, even the subject of nationalist aspiration and self-confidence. A salient aspect in the analysis by Melnick and Bernheim (2009), is the observation that for the 12 principles of the 'Public Health Code of Ethics', building relationships is crucial in building biopreparedness. Why? So that a consensus can be forged about making resource allocation decisions. Does that put Tanguay-Renaud's (2009) critique of Walzer's elevation of the political community in a different light? The relationship building is constitutive of a specific community, namely the community built to forge that allocation consensus. Whilst that does seem to be a political community, it is a different one than Walzer implies. Or is it? Melnick and Bernheim (2009) mention the public Town Hall meetings that took place to develop the 12 principles and the code. To what extent is a general political infrastructure a necessary condition to build a community for a specific purpose? How does that differentiate regions or organizational levels in how resilient they are as a professional or workplace community? And, can you build that special purpose community post hoc?

That is a question Zack (2009) explores. In a paper on disaster management the author writes that both

preparation and response require plans and both kinds of plans have ethical aspects. Is there an ethics of disaster preparation planning distinct from an ethics of disaster response planning? (Zack 2009: 55)

The author claims that in the Avian Flu pandemic, there was inadequate disaster preparation and we've only seen disaster response. Of course,

in disasters, our best plans may not be applicable. That we do not know beforehand which parts of our plans for disaster will fail to be applicable, itself puts restrictions on the whole dimension of planning for disaster. (Zack 2009: 58)

The obstacles in the Avian Flu pandemic - just as in the COVID-19 one - include a changing (mutating) viral target, time laps to vaccine, and limited resources such as hospital beds and ventilators. These obstacles determine the ethical characteristics of the disaster response. Zack (2009) sets out two models: Save the Greatest Number (SGN) and Save ALL who can be saved (SALL). Whilst SALL has the moral consensus, SGN is relative because it becomes an important model if we've messed up in preparations. As I write this, questions are being asked in the UK about elderly care home COVID-testing policies (disaster response), and why the UK had far less hospital beds per inhabitants than other European countries (disaster preparation). How these debates unfold can inform us how dynamics of justification and rhetoric 
actually play out. For Zack (2009), SALL is the model we must use in the preparation phase. Once we are in response mode we need to do things like medical triage. Hence, in response mode we switch to SGN but, argues Zack (2009), this can only be justified if there is a broad public debate, i.e. political community. Any disaster response will include a medical triage. Thus, SGN becomes a SGNW: save the greatest number Who ... - it is filling in the blank that requires a broad public debate to forge consensus around who to exclude (e.g. elderly, already ill, etc). Without such a consensus, one cannot overcome the problems of arbitrariness and of having accepted limitation before the fact. In other words, responding without preparation makes it impossible to re-solve - as in 'solve again' - Williams' (2005) first political question.

The COVID-19 pandemic is managed at different levels - international, national, organizational, household. Extreme situations are useful for analysing limits of categories and concepts. Can COVID-19 responses be used to identify specific characteristics of different levels of management (cf. Blok 2020 in this issue)? The scholarship in this journal on disaster management can provide a sound basis for that line of inquiry.

The second 'broad route' I suggested at the outset was an inquiry into work from an existentialist philosophy. I noticed we have very little on existentialism in our journal. An exception is MacMillan et al. (2012) who wrote a paper on existentialism as a philosophy of work and management. They offer three key insights:

(1) Existentialism places a primacy upon the individual and the existential self that is continually being formed within the workplace. (2) Existentialism allows for a coherent examination of individual and organisational-level decision making and ethics as an integral part of the philosophy. (3) Existentialism is inherently 'applied' and focused on 'process' in that it allows for an understanding of the meaning of work. (MacMillan et al. 2012: 27)

In Europe, existentialism came to prominence after WWII, as the continent went through a long period of recovery. Not merely economic recovery. People experienced confusion and disillusionment. Perhaps that is inextricably connected to economic recovery - note our prospects today are of U-shaped or even an L-shaped economic recovery. In any case, existentialism provided direction for individual life then, and perhaps it will do so again.

Existentialism is of course a range of philosophies but there are nevertheless some common tenets. One is the importance of death as a pivotal aspect of life's meaning. Another is that people are thrown into the world; that they exist before there is essence and cannot but create or construct essence and meaning. Choice and possibilities are both endless and the implication is an inescapable responsibility of the individual. One of the challenges individuals face is to live authentic lives in the indifference of the everydayness. MacMillan et al. (2012) argue that work is a suitable context to explore all of that. More precisely, work is a site where choices are put into action, where interactions with others constitute the work organisation as site, and where work has an everydayness.

There is of course one existentialist - although there is debate over whether he really was one - that seems most pertinent in today's context of a pandemic. That is Albert Camus, who never called himself an existentialist; even denied he was one - yes there is some irony in that. In Camus' novels, individuals face and overcome absurdity. For Camus, absurdity is caused by our expectation that the world is rational and just, and the experience of a world that is indifferent to all our expectations. Like many other people, I re-read Camus' La Peste (The Plague, Camus 1947). This novel about life in lockdown during a pandemic, actually becomes 
a different book when read in lockdown during a pandemic. The randomness of a pandemic is a cold shower of the world's indifference. The number games are as absurd in Camus' novel as they were two months ago (and still are when I'm writing this at the end of May 2020). Incomprehensible and inexplicable, unless that is not what they are meant to be doing.

For Camus, absurdity can be overcome by a 'leap of faith', the choice not to hold on to rational expectations of the world, but instead openly accept the irrationality of our choices. Here is the moment in which Camus got doubted as an existentialist. Perhaps today that can be the moment in which Camus becomes the more credible existentialist. Or can we still hold on to Sartre-style absolute agency? Could Camus then be one of the other existentialists we start to read in our philosophy of management scholarship? Is there a shared notion of humanism between Camus, Levinas and Tillich? This journal is developing scholarship on Levinas (e.g. Blok 2014, 2018; Faldetta 2019; Loumansky and Lewis 2013; Tajalli and Segal 2019) and Tillich is coming (Eabrasu 2019, and also currently some papers in the review process). But our journal has nothing on Camus yet. Nevertheless, Camus' picturing of openly accepting the irrationality of our choices, is strikingly relevant for a philosophy of management. Not only in The Plague, but also in the Myth of Sisyphus and The Stranger (Camus 1942a, b), the protagonists accept what comes, they play their role.

That is also literally what the doctor in The Plague says a number of times: the importance of playing one's role. I have always thought of that as one of the most dangerous situations we can be in, when we use 'just doing my role' as a justification for what we do. But this pandemic - and reading La Peste during the pandemic - made me see a different possibility. Namely when 'playing one's role' is not an excuse but rather the basis for making exceptions and becoming authentic. What else would you do? It is what I have seen the doctors, the nurses, virologists, and even the politicians do. We have seen people 'just doing their role' knowingly and openly inadequate, guessing, incomplete but nevertheless authentic. Most of us have been applauding health care workers, some of us also shop attendants. Yet despite the applause, they are not heroes. We tell them they are but they tell us that is not how they feel (see for example the recent CREW blogs ${ }^{1}$ ). They are 'just doing their role'. What else can they do? How different work and management becomes, all of a sudden.

\section{Compliance with Ethical Standards}

Conflict of Interest The author is editor-in-chief of this journal.

\section{References}

Blok, V. 2014. The metaphysics of collaboration: Identity, Unity and Difference in cross-sector partnerships for sustainable development. Philosophy of Management 13: 53-74.

\footnotetext{
${ }^{1}$ See CREW blogs edited by Scott Tindall: https://werugreenwich.wordpress.com/2020/04/27/its-like-awarzone-customers-were-fighting-over-toilet-paper-a-uk-supermarket-employees-experience-of-work-at-theoutbreak-of-the-coronavirus-pandemic/

and also https://werugreenwich.wordpress.com/2020/05/18/i-knew-exactly-what-this-call-was-and-i-brokedown-into-tears-a-car-rental-employees-experience-of-redundancy-at-the-outbreak-of-the-covid-19-pandemic/
} 
Blok, V. 2018. Philosophy of innovation: A research agenda. Philosophy of Management 17: 1-5.

Blok, V. 2020. What is (business) management?, Laying the Ground for a Philosophy of Management. Philosophy of Management. https://doi.org/10.1007/s40926-019-00126-9.

Camus, A. 1942a. L'Étranger. Paris: Gallimard.

Camus, A. 1942b. Le Mythe de Sisyphe. Paris: Gallimard.

Camus, A. 1947. La Peste. Paris: Gallimard.

Eabrasu, M. 2019. Gods are still in business - introduction to the symposium: God and management. Philosophy of Management 18: 293-302.

Faldetta, G. 2019. When relationships are broken: Restorative justice under a Levinasian approach. Philosophy of Management 18: 55-69.

John, S.D. 2009. Supreme emergencies, epistemic murkiness and epistemic transparency. Philosophy of Management 8: 3-12.

Loumansky, A., and D.A. Lewis. 2013. Levinasian approach to whistleblowing. Philosophy of Management 12: $27-48$.

MacMillan, S., A.R. Yue, and A.J. Mills. 2012. Both how and why: Considering existentialism as a philosophy of work and management. Philosophy of Management 11: 27-46.

Melnick, A.L., and R.G. Bernheim. 2009. Using the code of ethics in crisis management involving complex political environments: Determining ventilator allocation during an influenza pandemic. Philosophy of Management 8: 13-20.

Muhr, S.L., and J. Lemmergaard. 2009. Crisis, responsibility, death: Sacrifice and leadership in school shootings. Philosophy of Management 8: 21-30.

Tajalli, P., and S. Segal. 2019. Levinas, weber, and a hybrid framework for business ethics. Philosophy of Management 18: 71-88.

Tanguay-Renaud, F. 2009. Making sense of 'public' emergencies. Philosophy of Management 8: 31-53.

Williams, B. 2005. In the beginning was the deed. Realism and moralism in political argument. NJ, Princeton University Press: Princeton.

Zack, N. 2009. The ethics of disaster planning: Preparation vs response. Philosophy of Management 8: 55-66.

Publisher's Note Springer Nature remains neutral with regard to jurisdictional claims in published maps and institutional affiliations.

Wim Vandekerckhove The author is Reader in Business Ethics and co-director of the Centre for Research on Employment and Work (CREW) at the University of Greenwich, and a Visiting Fellow at the Centre for Governance \& Public Policy, Griffith University. He is editor-in-chief of Philosophy of Management. 